\title{
The Strange Case of the Scottish Independence Referendum. Some Elements of Comparison between the Scottish and Catalan Cases
}

L'étrange cas du référendum sur l'indépendance écossaise. Quelques éléments de comparaison entre les cas écossais et catalan

Nathalie Duclos

\section{(2) OpenEdition}

Journals

Electronic version

URL: http://journals.openedition.org/rfcb/384

DOI: $10.4000 / \mathrm{rfcb} .384$

ISSN: 2429-4373

\section{Publisher}

CRECIB - Centre de recherche et d'études en civilisation britannique

\section{Electronic reference}

Nathalie Duclos, «The Strange Case of the Scottish Independence Referendum. Some Elements of Comparison between the Scottish and Catalan Cases ", Revue Française de Civilisation Britannique [Online], XX-2 | 2015, Online since 23 July 2015, connection on 19 April 2019. URL : http:// journals.openedition.org/rfcb/384 ; DOI : 10.4000/rfcb.384

This text was automatically generated on 19 April 2019

\section{c)}

Revue française de civilisation britannique est mis à disposition selon les termes de la licence Creative Commons Attribution - Pas d'Utilisation Commerciale - Pas de Modification 4.0 International. 


\title{
The Strange Case of the Scottish Independence Referendum. Some Elements of Comparison between the Scottish and Catalan Cases
}

\author{
L'étrange cas du référendum sur l'indépendance écossaise. Quelques éléments de \\ comparaison entre les cas écossais et catalan
}

Nathalie Duclos

1 This article focusses on the main specificities of the Scottish independence referendum of 18 September 2014 from an international point of view. The Scottish independence referendum presented several unusual characteristics that were difficult to make sense of for non-Britons. One of the main points that caught the attention of European commentators was the fact that both Scotland and Catalonia had planned to organise independence referendums at about the same time. This often led to fears of the domino effect that a Scottish Yes vote might have, not just in Catalonia, but throughout the EU (in Spain, but also Belgium and Italy), and of the precedent that Scotland might set if it acceded to independence easily. Yet, paradoxically, the parallel that was systematically drawn between the Scottish and the Catalan cases also highlighted the main, crucial difference between them, which was that London had agreed to the Scottish referendum, while Madrid has strongly opposed the holding of a Catalan independence referendum and has repeatedly brought the matter before the Spanish Constitutional Court. As a consequence, the Scottish referendum happened perfectly legally, while the unofficial consultation (or "participative process", as it was known) organised in Catalonia on 9 November 2014 was a purely symbolic and political gesture, with no legal meaning. ${ }^{1}$ How can we make sense of the fact that the British Government allowed the Scottish independence referendum to take place, in a way that goes beyond international assumptions on British pragmatism? Why would London condone a move that could have led the UK to lose (at the very least) one third of its land mass and more than $8 \%$ of its 
inhabitants, when the power to organise referendums on constitutional matters was understood to be in the sole hands of British central institutions?

Equally surprising from an international perspective was the fact that an independence referendum was allowed in Scotland despite the absence of strong popular pressure for independence or even for a referendum. The Scottish independence referendum was not organised because a strong proportion of the Scottish population had been clamouring for one, but because the Scottish National Party (or SNP) had won a total majority of seats in the 2011 Scottish legislative election, a victory that was not primarily due to the SNP's support for the cause of independence. Outside observers often imagine the SNP to be a small, single-issue party going up against the two big British parties (the Labour and Conservative parties). That is to misrepresent both the political platform of the SNP, which is more than a pro-independence party, and its place in the Scottish party system, where it is one of the two major political parties (the other one being Labour). One cannot make sense of the Scottish independence referendum without understanding the differences in party systems and party competition in Scotland and in the UK as a whole.

The main reasons that London put forward in order to condone the holding of a Scottish independence referendum were first, that Scotland had a right to self-determination, and secondly, that the SNP had won a mandate to organise a referendum. These two reasons led to the matter being swiftly settled by a political deal between Edinburgh and London, signed in October 2012, two years before the actual referendum was held. This again clearly marks the Scottish case out from the Catalan one, which is characterised by constitutional conflict.

\section{Scotland's right to self-determination and its status as a nation}

4 The issue of Scotland's right to self-determination, and the related issue of the British recognition of Scotland's status as a nation, will be examined first. In the inaugural report of its Scotland Analysis series published in 2013 and 2014, the then British Government (a Conservative-Liberal Democrat coalition government) linked its acceptance of a Scottish independence referendum with what it described as British Governments' long-term acceptance of Scotland's right to independence. It started by clearly "recognis[ing] that Scotland has the right to leave the UK if a majority of people vote for it in the referendum in 2014: that choice rests with people in Scotland." It then claimed that it was far from the first British Government to recognise this: "[s]uccessive UK Governments have said that, should a majority of people in any part of the multi-national UK express a clear desire to leave it through a fair and democratic process, the UK Government would not seek to prevent that happening". ${ }^{3}$ Just like previous governments, the current one had "consistently stated that Scotland could be a viable independent state and Scotland ha[d] the right to choose that path". ${ }^{4}$ Interestingly, in the same report, it shied away from saying that this amounted to Scotland having a primary right to secession or self-determination. On the contrary, it was noted that:

Outside the colonial context, the principle of self-determination is controversial. The Canadian Supreme Court has held that "a right to secession only arises under the principle of self-determination of peoples at international law where 'a people' is governed as part of a colonial empire". In metropolitan territories such as Scotland, "peoples are expected to achieve self-determination within the framework of their existing state". ${ }^{5}$ 

level, the fact is that by saying that Scotland had the "right to leave the UK" and the "right to choose [the] path" of independence, the British Government was recognising Scotland's right to self-determination (or secession), even though it chose not to name it as such.

Twenty years before, Margaret Thatcher had had no such qualms about speaking of Scottish self-determination. In her memoirs, she had noted that " $[a] s$ a nation, they [the Scots] have an undoubted right to national self-determination; thus far they have exercised that right by joining and remaining in the Union. Should they determine on independence no English party or politician would stand in their way". ${ }^{6}$ To her, this "right to national self-determination" did not give Scotland the right to more autonomy within the UK in the form of a devolved Parliament (Scotland, she had said, "cannot claim devolution as a right of nationhood inside the Union"7), but it did mean that Scotland could unilaterally choose to become independent. Thatcher's successor, John Major, had also asserted that "no nation could be held irrevocably in a Union against its will"; 8 in other words, Scotland had the right to leave the Union if it wished to do so. The Scottish case is therefore rather unusual in the sense that, at least in the recent past, Scottish nationalists have not needed to convince British Unionist politicians of the legitimacy of Scotland's right to secede from the UK.

7 The Catalan case is radically different from the Scottish one in that respect, as a brief analysis of nationalist argumentation demonstrates. On 29 September 2014, the Catalan president presented the Government of Catalonia's independence White Paper. ${ }^{9}$ It is notable that the very first part of the White Paper, entitled "Legitimisation of the process of self-determination", in fact aimed at legitimising both the process and the very principle of self-determination. This was done in three ways: first, the "people's right to democratically decide" was asserted; secondly, self-determination was described as "an inalienable right given the nature of Catalonia as a nation"; and thirdly, it was presented as "the last resort to remedy an unjust situation". Generally speaking, theories of secession are divided into two categories: those which present secession as a primary right, and remedial-right-only theories, according to which secession is only justified in cases where it can be a remedy in an unjust situation. In this independence White Paper, Catalan nationalists invoked both types of theories. To them, Catalan self-determination is legitimate both on the grounds that Catalonia is a nation and a liberal democracy, and on the grounds that selfdetermination is a morally-justified remedy to the unfair way Catalonia has been treated by Spain, to what is described as "Spain's (systematic) intervention and questioning of regional autonomy", ${ }^{10}$ in other words, Spanish intrusion into exclusive Catalonian powers. This White Paper came two years after the Catalan Parliament had adopted a motion (or "resolution" as they are known in Spain) asserting the Catalan people's "right to decide", which has become part of the Catalan nationalist case for the right to self-determination. 11

8 In Scotland, nationalist discourse has commonly been built around vague appeals to Scottish people's "right to decide", but there had seldom been ambitious attempts to build an intellectual case for Scotland's right to self-determination until just before the independence referendum itself. After the SNP's first electoral victory of May 2007, at a time when the British Government had not yet agreed to the holding of an independence referendum in Scotland, the first White Paper that was published by the nationalist Government noted that the Scottish people had always retained a right to "determine their own constitutional future". However, the SNP Government did not give any philosophical, 
moral or any other type of justification for that claim beyond the argument of historical precedent:

The Union between Scotland and the other nations of the UK did not remove from the people of Scotland their fundamental political right to determine their own constitutional future. The Republic of Ireland and the countries of the former British Empire chose to move to independence from similar constitutional arrangements. The people of Scotland remain sovereign and have the same right to choose the form of their own Government as the peoples of other nations that have secured independence after periods of union with, or in, other states. ${ }^{12}$

The second White Paper published during the SNP's first term, again in the context of the so-called "national conversation" on Scotland's constitutional future, was even less concerned with defending Scotland's right to self-determination, simply making the very general statement that "[i]n recent years, many countries have gained independence, recognising that it is right that sovereign nations are responsible for their own decisions, while still working in partnership with other nations." ${ }^{13}$ Finally, in the independence White Paper of November 2013, the principle of self-determination was invoked twice, but not once to justify the holding of an independence referendum: it was only invoked to justify local self-determination and to allow the Scottish Government to assert its belief in local decision-making (and to rebut accusations of SNP centralism). Only in the draft Scottish Independence Bill of June 2014 could one read a more sophisticated defence of Scotland's right to self-determination:

Self-determination developed during the $20^{\text {th }}$ century and has been codified in the fundamental and universal documents of the international system, such as the Charter of the United Nations in 1945 and the International Covenants on Civil and Political Rights and Economic, Social and Cultural Rights of 1966. The referendum, and becoming an independent country, would be an act of self-determination by the people of Scotland. However self-determination is permanent and that principle would continue to be respected following independence by the on-going democratic nature of Government in Scotland. ${ }^{14}$

10 What is surprising is that this defence of the principle of self-determination only came at a time when the independence referendum was a given, and in no need to be justified. By contrast, in the Catalan case, the nationalist argumentation on self-determination was made in order to convince the Spanish authorities of the legitimacy of a Catalan independence referendum.

11 It is here argued that the differences in the British and Spanish Governments' attitudes towards Scottish and Catalan demands for self-determination are both a cause and a consequence of the differences in the way that Scotland and Catalonia are perceived as political units. To put it simply, Britain's recognition of Scotland's primary right to political self-determination can be linked to its recognition of Scotland's status as a nation. Rather uniquely in Europe, ever since the birth of the first pro-independence organisations in Scotland in the inter-war years, their aim has never been to gain official recognition of Scotland's nationhood, which has not been a bone of contention in the UK. Interestingly, Alex Salmond's preface to the 2013 independence White Paper still starts with the reminder that "Scotland is an ancient nation". ${ }^{15}$ The introduction to the Catalan independence White Paper similarly underlines the idea that "Catalonia has always felt like a nation". ${ }^{16}$ However, the Catalan White Paper (contrary to the Scottish one) then goes on to explain that not being recognised as a nation in its own right has been a long-standing sticking point between Catalonia and Spain. Speaking of the 1978 Spanish Constitution, the Catalan White Paper regrets that "article 2 CE used the terms 'nationalities' and 'regions' to 
refer to the possible national communities in the Spanish State that wanted to achieve a certain degree of political autonomy, while it reserved the term 'nation' for Spain." ${ }^{17}$ In contrast, the preamble to the Statute of Autonomy of Catalonia (which could be described as Catalonia's regional constitution) ratified by referendum in 2006 asserts Catalonia's status as a nation: "In reflection of the feelings and the wishes of the citizens of Catalonia, the Parliament of Catalonia has defined Catalonia as a nation by an ample majority." ${ }^{18}$ However, this is a rewriting of the original draft which simply defined Catalonia as a nation, without the specification that it had been defined as such by the Parliament of Catalonia (the implication being, of course, that Spanish central institutions did not agree to this selfdefinition). Article 1 of the 2005 draft Statute of Autonomy was entitled "the Catalan nation" and opened on the words "Catalonia is a nation." ${ }^{19}$ This was one of many articles contested by the People's Party (at the time the main opposition party in the Spanish Congress) and ruled unconstitutional by the Spanish Constitutional Court in $2010 .{ }^{20}$ Even before the ruling, the text was amended so as to make it clear that there was no agreement on Catalonia's status as a nation, and the reminder that "[t]he Spanish Constitution, in its second Article, recognises the national reality of Catalonia as a nationality" (and therefore not as a nation) was also added. ${ }^{21}$

London, on the other hand, has openly recognised the multinational character of the British State and Scotland's status as a nation within it. As early as 1954, the Royal Commission on Scottish Affairs had acknowledged that "Scotland is a nation and voluntarily entered into union with England as a partner and not as a dependency". ${ }^{22}$ More recently, the British Government report mentioned earlier repeatedly described the UK as a "multinational" or "multi-nation" state ${ }^{23}$ and acknowledged that it had been one ever since its foundation in 1707: "The Acts of Union of 1707 [...] marked the beginning of a single multinational state, which has become one of the most successful partnerships of nations in history." ${ }^{4}$

\section{The doctrine of the mandate, and the independence referendum as a political rather than a legal- constitutional matter}

13 The other major reason behind London's agreement to the holding of a Scottish independence referendum lies in its belief in what has been termed the "doctrine of the mandate", ${ }^{25}$ a doctrine whereby obtaining a majority in an election gives a party a political and moral mandate to implement any policy that is part of its election programme. This is a belief that all British parties (including the SNP) share and that is arguably at the very heart of the British political system. Hence, when the SNP won a total majority of seats in the Scottish Parliament in 2011, all of the Unionist parties agreed that the nationalists now had a mandate to organise an independence referendum, as this nationalist promise had been at the heart of the SNP's political programme for a decade and a half. ${ }^{26}$ Interestingly, obtaining a relative majority in 2007 (as opposed to an overall one) was not deemed sufficient to give the SNP a mandate to organise a referendum. Until 2011, the typical Unionist attitude to an independence referendum was that, in the words of a Liberal Democrat, "[p]oliticians should not support referendums on policies which they do not back" ${ }^{27}$ This view was no longer deemed tenable after the 2011 Scottish election. All the Unionist parties then agreed that a Scottish independence referendum was both legitimate and inevitable. The following three quotes, from the same debate in the House of Commons and from representatives of the three major Unionist parties, clearly 
demonstrate this, as well as being evidence of a shared belief in the doctrine of the mandate.

The Secretary of State for Scotland, Michael Moore (a Liberal Democrat), noted that the referendum process "began with the Scottish National Party's victory in the May 2011 Scottish parliamentary elections and its manifesto pledge to hold an independence referendum", and he "recognised the political mandate that the SNP had secured for a referendum." ${ }^{28}$ A Conservative MP similarly declared: "I am a democrat, and I fully accept that the SNP won the majority of seats in the Scottish Parliament. [...]. [The constitutional question] was part of the SNP manifesto, and it is perfectly legitimate for it to hold the referendum." ${ }^{29}$ Finally, a Labour MP also argued that "the SNP has won the mandate to hold a referendum - of course it has. The SNP won the right, through its election manifesto, to ask the question of the Scottish people." ${ }^{30}$

In summary, London agreed to the holding of an independence referendum because it was believed that by winning an overall majority of seats in 2011, the SNP had won the right to see that particular promise implemented, even though, ironically, it was not the referendum promise that had allowed the SNP to win the election in the first place. What's more, the SNP arguably had not thought that it would be in a position to implement its referendum promise, especially not so soon after winning power for the first time in its history. Until then, nobody had expected any one political party to be able to win a total majority of seats in the Scottish Parliament, due to the mixed (and therefore partly proportional) electoral system used for Scottish elections. However that may be, what is unusual about the Scottish case is that the holding of an independence referendum was governed by a belief in a political doctrine (the doctrine of the mandate), rather than by the upholding of a constitutional rule.

In the Catalan case, the election in November 2012 of a parliamentary majority ${ }^{31}$ "composed of parties that included the holding of a consultation [on Catalonia's constitutional status] as a priority objective in their election programmes" 32 was not enough to convince the Spanish Government of the legitimacy of such a consultation. Neither was the Spanish Government convinced by the Catalan Parliament's motion stating that it had "approved, with qualified majorities, its support for the right to decide of Catalans, and ha[d] established the mandate of dialogue and negotiation with the Spanish Government with the aim of exercising it through a democratic poll." ${ }^{33}$ In Spain, the argument of the mandate is therefore felt to be too weak a political argument on which to found the claim to an independence referendum. As a consequence, Catalan nationalists have tried to build their case on constitutional and legal arguments, as opposed to political ones.

17 First, they suggested the British option of a temporary transfer of the legal power to organise a referendum from the central authorities to the devolved ones. To that end, in January 2014, the Catalan Parliament submitted to the Spanish Congress a motion ${ }^{34}$ demanding that an independence referendum be organised under article 150.2 of the Spanish Constitution. This article states that "[t]he State may transfer or delegate to the Selfgoverning Communities, through an organic act, some of its powers which by their very nature can be transferred or delegated." ${ }^{35}$ The Catalan motion acknowledged that "[t]he authorization to call referendums is technically established as a power of the Spanish State, in accordance with Article 149.1.32 of the Constitution", but this also meant that it was "a power that can be devolved or delegated on the basis of Article 150.2 of the Constitution". It was underlined elsewhere that this was "precisely what the UK Parliament [had done] with the Scottish 
Parliament, as signed in the Edinburgh Agreement, allowing the temporary transfer of legal authority to organise the independence referendum" ${ }^{36}$ The same motion clearly appealed to the British (and Canadian) precedent in a wider sense, stating that:

The holding of a consultation must be considered a normal scenario that is fully comparable with that of countries with a democratic tradition and nature, such as Canada and Great Britain which, faced with demands made by a national community linked to a territory that is clearly delimited politically and administratively (Quebec and Scotland, respectively), consider that the best form of expression of this collective will is a referendum. ${ }^{37}$

A previous motion (adopted by the Catalan Parliament in September 2013) had already presented the UK and Canada as models of good practice, as countries where legal solutions had been found to make possible the holding of independence referendums:

$[T]$ here are several legal channels within the current legal frameworks that could enable the request [to discuss the holding of an independence referendum] by the President of the Generalitat to be satisfied, and that these channels depend only on the political will of the Spanish Government [...]. [A] political will to reach an agreement has existed in similar situations, such as those of the United Kingdom and Scotland or Canada and Quebec, where the legal frameworks have been no obstacle to the holding of a poll among Scottish and Quebec citizens about their political future. ${ }^{38}$

However, the Spanish Congress massively voted against the Catalan motion of January 2014 demanding the transfer to Barcelona of the legal power to organise a referendum. ${ }^{39}$ The Catalan Parliament then changed tactics, and decided to create its own legal path to an independence referendum. On 19 September 2014, it endorsed a law allowing a nonbinding consultation. ${ }^{40}$ This led Madrid to launch an appeal to the Spanish Constitutional Court, which resulted in an injunction suspending the Catalan law and decree allowing the referendum. The Catalonian consultation was organised in spite of the court injunction, which led to yet another constitutional challenge from the Spanish State, which is suing the Catalan president for "disobedience and dishonesty". ${ }^{41}$ We see that the debate over the holding of a Catalan independence referendum is largely shaped by constitutional conflict and legal and judicial battles. As argued by two Barcelonan academics:

For the Spanish Government, defending the law and the constitution - which explicitly upholds the "indissoluble unity of the Spanish nation" - seems to be the main, and sometimes the only, justification for denying Catalans the possibility to decide on, or even formally express their support for, independence. As a result, the resort to courts has become a key instrument to deal with the conflict and, ultimately, preserve the unity of Spain. ${ }^{42}$

In the UK, in the absence of a codified constitution on the Spanish model, one has to turn to the Scotland Act 1998, which is deemed to have constitutional value, to determine which level of government has the right to organise referendums and on what matters. The Scotland Act does not explicitly reserve the organisation of referendums to the Westminster Parliament, though it does reserve to Westminster "the Union of the Kingdoms of Scotland and England". ${ }^{43}$ It can therefore be argued that a referendum on ending that Union is also a matter reserved to Westminster. ${ }^{44}$ However, what is significant is that Scottish devolved institutions were not presented with a Catalan-type of alternative between legally challenging such an understanding of the Scotland Act, or organising an illegal consultation, and that they were able to settle the matter through a political deal, the Edinburgh Agreement of October 2012, rather than through a legal and constitutional challenge. As stated in the opening lines of the Edinburgh Agreement, "[t]he United 
Kingdom Government and the Scottish Government have agreed to work together to ensure that a referendum on Scottish independence can take place." 45

\section{Conclusion}

21 Much more could be said about the differences between the Scottish and Catalan cases, especially in the arguments made by their respective independence movements, not least in terms of the importance given to linguistic nationalism (very high in Catalonia, very low in Scotland) and in terms of the perceived economic position of these territories (Catalonia is undoubtedly the economic powerhouse of Spain; while nationalists and Unionists are divided over Scotland's economic standing, nobody is arguing that Scotland is the wealthiest region in the UK). The main point made by this article still stands. Comparing the Scottish and Catalan cases makes the Scottish case appear quite remarkable. A Scottish independence referendum was allowed by the British Government even though it could have blocked it by legal and constitutional means. Scotland's right to self-determination has long been acknowledged, as has been its status as a nation within the UK State.

The case of Quebec is arguably closer to that of Scotland than Catalonia is. Quebec legally organised two provincial referendums ${ }^{46}$ (one in 1980 and the other in 1995), and both were held after electoral victories by the sovereignist Parti Québécois, which, like the SNP, had renounced its original plan to demand independence as soon as it won power, in favour of the promise that it would consult the population first through the holding of a referendum. Moreover, Quebec's status as a nation within the Canadian federation was recognised by the federal Government in $2006 .{ }^{47}$ However, the questions asked in the two Quebec referendums contained the words sovereign/sovereignty, but not the words secession, independence, or even self-determination, meaning that the status of these consultations as independence referendums could have been challenged, had they been won by the sovereignists. ${ }^{48}$ By contrast, the use of the adjective independent in the Scottish referendum question made things very clear. Moreover, the Clarity Act voted in Canada in 2000 allows for the possibility that in the future, a simple majority vote in a Quebec referendum will not be enough to launch the secession process and that a qualified majority will be needed. ${ }^{49}$ There were no such reservations in Scotland, where a simple " $50 \%$ plus one" majority would have been enough to launch independence negotiations. So it seems that in the Scottish case, the main obstacle on the road to secession was the Scottish people, a majority of which remained unconvinced of the merits of independence in September 2014. This hurdle could be rather easier to overcome in the near future than the legal and constitutional obstacles that the Catalan nationalists still have to face.

\section{BIBLIOGRAPHY}

Books and research articles 
BOCHEL, John, DENVER, David \& MACARTNEY, Allan (eds.). The Referendum Experience. Scotland 1979. Aberdeen: Aberdeen University Press, 1981.

RUIZ ALMENDRAL Violeta. "Spanish Court Strikes down Parts of Catalonia's Draft Constitution". Federations Magazine, December 2010/January 2011.

THATCHER, Margaret. The Downing Street Years. London: HarperCollins, 1993.

Official publications (by governments, parliaments, commissions and political parties)

CATALAN GOVERNMENT. The National Transition of Catalonia. September 2014.

http://web.gencat.cat/en/actualitat/detall/20140930_Llibre-blanc-sobre-la-Transicio-Nacionalde-Catalunya-00001.

CONVERGÈNCIA i UNIÓ. Programa Electoral 2012. Catalunya 2020. http://www.ciu.cat/ media/76990.pdf.

GREAT BRITAIN HOUSE OF COMMONS. Scotland in the Union. A Partnership for Good. Cm. 2225, London: The Stationery Office, March 1993.

GREAT BRITAIN HOUSE OF COMMONS. Hansard. 7 May 2008, vol. 475, col. 696.

GREAT BRITAIN HOUSE OF COMMONS. Hansard. 15 January 2013, vol. 556, col. 742-802.

GREAT BRITAIN HOUSE OF COMMONS SCOTTISH AFFAIRS COMMITTEE. Inquiry into the Referendum on Separation for Scotland. Session 2010-12, http://www.publications.parliament.uk/pa/cm201012/ cmselect/cmscotaf/writev/referendum/rs13.htm.

HM GOVERNMENT. Scotland Analysis: Devolution and the Implications of Scottish Independence. $\mathrm{Cm}$ 8554, London: The Stationery Office, February 2013.

HM GOVERNMENT and SCOTTISH GOVERNMENT. Agreement between the United Kingdom Government and the Scottish Government on a Referendum on Independence for Scotland. 15 October 2012.

ROYAL COMMISSION ON SCOTTISH AFFAIRS. Report. Cmnd. 9212, Edinburgh: HMSO, July 1954. SCOTTISH GOVERNMENT. Choosing Scotland's Future - A National Conversation. Independence and Responsibility in the Modern World. Edinburgh: Scottish Government, 2007.

SCOTTISH GOVERNMENT. Your Scotland, Your Voice. Edinburgh: Scottish Government, 2009. SCOTTISH GOVERNMENT. Scotland's Future. Your Guide to an Independent Scotland. Edinburgh: Scottish Government, 2014.

Laws, constitutions, rulings and parliamentary motions

CANADIAN HOUSE OF COMMONS, $39^{\text {th }}$ Parliament, $1^{\text {st }}$ Session. Hansard. Number 087, 27 November 2006.

CANADIAN PARLIAMENT. Clarity Act 2000.

CATALAN PARLAMENT. Organic law 6/2006 of 19 July, on the Reform of the Statute of Autonomy of Catalonia. http://www.parlament.cat/porteso/estatut/estatut_angles_100506.pdf.

CATALAN PARLIAMENT. Resolution 742/IX on "the general political orientation of the Government of Catalonia”, 27 September 2012.

CATALAN PARLIAMENT. Resolution 5/X "adopting the Declaration of sovereignty and right to decide of the people of Catalonia", 23 January 2013. 
CATALAN PARLIAMENT. Resolution 323/X "on the general political orientation of the Government of Catalonia”, 27 September 2013.

CATALAN PARLIAMENT. Resolution 479/X "by which it was agreed to submit to the Presiding Board of Congress the draft organic act delegating to the Generalitat of Catalonia power to authorize, call and hold a referendum on the political future of Catalonia", 16 January 2014.

CATALAN PARLIAMENT. Law authorizing a non-binding consultation on independence and participation, 19 September 2014. http://web.gencat.cat/en/actualitat/detall/20140919_Llei-deconsultes-populars-no-referendaries-i-participacio-ciutadana.

\section{SPANISH CONSTITUTION of 1978.}

http://www.lamoncloa.gob.es/lang/en/espana/leyfundamental/Paginas/index.aspx.

SPANISH CONSTITUTIONAL COURT. Pleno. Sentencia 31/2010, de 28 de junio de 2010 (BOE núm. 172, de 16 de julio de 2010),

http://www.tribunalconstitucional.es/es/jurisprudencia/paginas/Sentencia.aspx?cod=16273.

STATUTE OF AUTONOMY OF CATALONIA (2005 draft). http://www.parlament.cat/porteso/ estatut/estatut_english.pdf.

STATUTE OF AUTONOMY OF CATALONIA (text approved in 2006). http://web.gencat.cat/en/ generalitat/estatut/estatut2006.

UNITED KINGDOM PARLIAMENT. Scotland Act 1998, Schedule 5, part I.

Websites

Website on the Catalan consultation of November 2014 (1):

http://www.participa2014.cat/resultats/dades/es/escr-tot-resum.html.

Website on the Catalan consultation of November 2014 (2):

http://www.cataloniavotes.eu/spanish-congress-rejects-the-uk-referendum-model-forcatalonia/.

Government of Catalonia (press release):

http://www.catalangovernment.eu/pres_gov/AppJava/Government/pressnotice/ pressnotice-275027.html.

London School of Economics blog: http://blogs.lse.ac.uk/europpblog/2014/11/04/using-spanishlaw-to-block-catalonias-independence-consultation-may-simply-encourage-catalans-toconstruct-their-own-alternative-legality/.

\section{NOTES}

1. Around 2.2 million people (out of a possible 5.4 million voters) took part. The questions asked were "Do you want Catalonia to be a State?" and "If so, do you want that State to be independent?". 80.76\% voted Yes to both questions. See: http://www.participa2014.cat/resultats/dades/es/escr-tot-resum.html.

2. HM GOVERNMENT, Scotland Analysis: Devolution and the Implications of Scottish Independence, $\mathrm{Cm}$. 8554, London: The Stationery Office, February 2013, p. 5.

3. Ibid., p. 32.

4. Ibid. 
5. Ibid., p. 106.

6. Margaret THATCHER, The Downing Street Years, London: HarperCollins, 1993, p. 624.

7. Ibid.

8. GREAT BRITAIN HOUSE OF COMMONS, Scotland in the Union. A Partnership for Good, "Foreword by the Prime Minister", Cm. 2225, London: The Stationery Office, March 1993, p. 5.

9. CATALAN GOVERNMENT, The National Transition of Catalonia (English version of the White Paper entitled Transició Nacional de Catalunya), September 2014. The English version can be downloaded from the following link:

http://web.gencat.cat/en/actualitat/detall/20140930_Llibre-blanc-sobre-la-Transicio-Nacionalde-Catalunya-00001.

10. Ibid., p. 20.

11. Resolution 742/IX of the Parliament of Catalonia on "the general political orientation of the Government of Catalonia", adopted on 27 September 2012. Further resolutions confirmed this, such as resolution 5/X of the Parliament of Catalonia "adopting the Declaration of sovereignty and right to decide of the people of Catalonia", voted on 23 January 2013. See the website of the Parliament of Catalonia:

http://www.parlament.cat/web/documentacio/altres-versions/resolucions-versions.

12. SCOTTISH GOVERNMENT, Choosing Scotland's Future - A National Conversation. Independence and Responsibility in the Modern World, Edinburgh: Scottish Government, 2007, p. 19.

13. SCOTTISH GOVERNMENT, Your Scotland, Your Voice, Edinburgh: Scottish Government, 2009, p. 18.

14. SCOTTISH GOVERNMENT, The Scottish Independence Bill: a Consultation on an Interim Constitution for Scotland, Edinburgh: Scottish Government, 2014, p. 28.

15. SCOTTISH GOVERNMENT, Scotland's Future. Your Guide to an Independent Scotland, Edinburgh: Scottish Government, 2014, p. viii.

16. CATALAN GOVERNMENT, The National Transition of Catalonia, op. cit., p. 6.

17. Ibid., p. 22.

18. See the website of the Government of Catalonia:

http://web.gencat.cat/en/generalitat/estatut/estatut2006/preambul/.

19. The 2005 draft Statute of Autonomy of Catalonia can be found here: http:// www.parlament.cat/porteso/estatut/estatut_english.pdf.

20. The reference to the ruling by the Spanish Constitutional Court is the following: Pleno. Sentencia 31/2010, de 28 de junio de 2010 (BOE núm. 172, de 16 de julio de 2010). It can be read on the website of the Constitutional Court:

http://www.tribunalconstitucional.es/es/jurisprudencia/paginas/Sentencia.aspx?cod=16273.

21. Organic law 6/2006 of 19 July, on the Reform of the Statute of Autonomy of Catalonia. For an English version of the law, see: http://www.parlament.cat/porteso/estatut/ estatut_angles_100506.pdf. For an article listing the key articles of the original Statute of Autonomy struck down by the Spanish Constitutional Court, see: Violeta Ruiz Almendral, "Spanish Court Strikes down Parts of Catalonia's Draft Constitution", Federations Magazine, December 2010/January 2011.

22. ROYAL COMMISSION ON SCOTTISH AFFAIRS, Report, Cmd. 9212, July 1954, p. 12.

23. HM GOVERNMENT, Scotland Analysis: Devolution and the Implications of Scottish Independence, op. cit., pp. 16, 18, 21 for example.

24. Ibid., p. 16.

25. See for instance John BOCHEL, David DENVER \& Allan MACARTNEY (eds.), The Referendum Experience. Scotland 1979, Aberdeen: Aberdeen University Press, 1981, p. 171.

26. Until the birth of the Scottish Parliament, the SNP had argued that there was no need for an independence referendum: all that was needed for Scotland to demand independence was for the SNP to gain a majority of Scottish seats in the British House of Commons. 
27. Quote by Robert Brown. GREAT BRITAIN HOUSE OF COMMONS, Hansard, 7 May 2008, vol. 475, col. 696.

28. Quote by Michael Moore. GREAT BRITAIN HOUSE OF COMMONS, Hansard, 15 January 2013, vol. 556, col. 742 .

29. Quote by Iain Stewart. Ibid., col. 802.

30. Quote by Anas Sarwar. Ibid., col. 798.

31. The nationalist alliance CiU (or Convergència i Unió, Convergence and Union) came first with 50 seats out of a total of 135 seats in the Parliament of Catalonia. Parties supporting a referendum on the independence of Catalonia won more than half of the total number of seats. See for instance the electoral programme of $\mathrm{CiU}$ for the 2012 Catalan elections: Convergència i Unió, Programa Electoral 2012. Catalunya 2020, http://www.ciu.cat/media/76990.pdf.

32. From resolution $479 / \mathrm{X}$ of the Parliament of Catalonia "by which it was agreed to submit to the Presiding Board of Congress the draft organic act delegating to the Generalitat of Catalonia power to authorize, call and hold a referendum on the political future of Catalonia". Resolution adopted on 16 January 2014. See the website of the Parliament of Catalonia: http://www.parlament.cat/web/ documentacio/altres-versions/resolucions-versions.

33. Resolution 323/X of the Parliament of Catalonia "on the general political orientation of the Government of Catalonia", voted on 27 September 2013.

(http://www.parlament.cat/web/documentacio/altres-versions/resolucions-versions.)

34. Resolution 479/X of the Parliament of Catalonia, op. cit.

35. 1978 Spanish Constitution, in English on the website of the Spanish Government: http:// www.lamoncloa.gob.es/lang/en/espana/leyfundamental/Paginas/index.aspx.

36. http://www.cataloniavotes.eu/spanish-congress-rejects-the-uk-referendum-model-forcatalonia/.

37. Resolution 479/X of the Parliament of Catalonia, op. cit.

38. Resolution $323 \mathrm{X}$, op. cit.

39. 299 votes against the motion, 47 in favour and one abstention.

40. See the website of the Government of Catalonia:

http://web.gencat.cat/en/actualitat/detall/20140919_Llei-de-consultes-populars-no-

referendaries-i-participacio-ciutadana. See also the following press release on the Government of Catalonia's website:

http://www.catalangovernment.eu/pres_gov/AppJava/Government/pressnotice/

pressnotice-275027.html.

41. See for instance: Lianna Brinded, "Catalonia Independence: Spain Sues Catalan President for 'Disobedience and Dishonesty"', International Business Times, 12 November 2014, http:// www.ibtimes.co.uk/catalonia-independence-spain-sues-catalan-president-disobediencedishonesty-1474459.

42. See the London School of Economics blog: http://blogs.lse.ac.uk/europpblog/2014/11/04/using-spanish-law-to-block-cataloniasindependence-consultation-may-simply-encourage-catalans-to-construct-their-own-alternativelegality/.

43. Scotland Act 1998, Schedule 5, part I, article 1 (b).

44. Read for example Aidan O'Neill QC's written evidence to the Scottish Affairs Committee of the House of Commons, in the context of its Inquiry into the Referendum on Separation for Scotland, session 2010-12.

(http://www.publications.parliament.uk/pa/cm201012/cmselect/cmscotaf/writev/referendum/ rs13.htm.)

45. Edinburgh Agreement, or "Agreement between the United Kingdom Government and the Scottish Government on a Referendum on Independence for Scotland", October 2012.

46. Canadian provinces have the power to organise referendums. 
47. Until 2006, the Quebec sovereignists, like the Catalan nationalists, had fought for Quebec to be recognised as a separate nation within Canada. Federal Government recognition had come with a motion tabled by Canadian Prime Minister Stephen Harper and voted overwhelmingly in the Canadian House of Commons on 27 November 2006. The motion states that "this House recognize that the Québécois form a nation within a united Canada". CANADIAN HOUSE OF COMMONS, $39^{\text {th }}$ Parliament, $1^{\text {st }}$ Session, Hansard, number 087, 27 November 2006.

48. The English version of the question asked in 1980 was: "The Government of Quebec has made public its proposal to negotiate a new agreement with the rest of Canada, based on the equality of nations; this agreement would enable Quebec to acquire the exclusive power to make its laws, levy its taxes and establish relations abroad - in other words, sovereignty - and at the same time to maintain with Canada an economic association including a common currency; any change in political status resulting from these negotiations will only be implemented with popular approval through another referendum; on these terms, do you give the Government of Quebec the mandate to negotiate the proposed agreement between Quebec and Canada?". The English version of the question asked in 1995 was: "Do you agree that Quebec should become sovereign after having made a formal offer to Canada for a new economic and political partnership within the scope of the bill respecting the future of Quebec and of the agreement signed on June 12, 1995?".

49. Clarity Act, article 2 (2): "In considering whether there has been a clear expression of a will by a clear majority of the population of a province that the province cease to be part of Canada, the House of Commons shall take into account (a) the size of the majority of valid votes cast in favour of the secessionist option- (b) the percentage of eligible voters voting in the referendum".

\section{ABSTRACTS}

The Scottish independence referendum of 18 September 2014 was rather unique from an international perspective, as a comparison between the cases of Scotland and Catalonia clearly reveals. Contrary to its Catalan equivalent, the Scottish referendum was perfectly legal and accepted by London, though London could have blocked it by legal and constitutional means. Two reasons explain this. First, Scotland is seen as having a right to self-determination as one of the nations of the multinational UK (whereas Catalonia is not considered as a nation by Madrid). Secondly, the British political class believes in the political doctrine of the mandate, according to which, by winning a total majority of seats in the 2011 Scottish Parliament elections, the SNP won a mandate to organise an independence referendum. This led to a political deal (known as the Edinburgh Agreement) between Edinburgh and London. By contrast, the relations between Catalonia and the central Spanish institutions are governed by constitutional conflict.

Le référendum d'autodétermination écossais du 18 septembre 2014 fut assez unique au plan international, comme le révèle clairement une comparaison entre les cas écossais et catalan. Contrairement à son équivalent catalan, le référendum écossais fut parfaitement légal et accepté par Londres, alors même que Londres aurait eu les moyens légaux et constitutionnels d'en empêcher l'organisation. Deux raisons l'expliquent. D'une part, l'Écosse est vue comme ayant le droit à l'autodétermination en tant que nation constitutive d'un Royaume-Uni multinational (tandis que la Catalogne n'est pas considérée comme une nation par Madrid). D'autre part, la classe politique britannique croit dans la théorie politique du "mandat", selon laquelle, en remportant la majorité absolue des sièges aux élections législatives écossaises de 2011, le SNP a 
obtenu un "mandat», c'est-à-dire la légitimité politique, pour organiser un référendum d'autodétermination. Cela a abouti à un accord politique (dit accord d'Édimbourg) entre Édimbourg et Londres. Loin de reposer sur la négociation politique, les relations entre la Catalogne et les institutions centrales espagnoles sont régies par des conflits d'ordre constitutionnel.

INDEX

Mots-clés: Écosse, Catalogne, référendum sur l'indépendance, auto-détermination Keywords: Scotland, Catalonia, independence referendum, self-determination

\section{AUTHOR}

NATHALIE DUCLOS

Université de Toulouse 2 - Jean Jaurès 